\title{
Passado a limpo
}

Cleber Araújo Cabral ${ }^{1}$

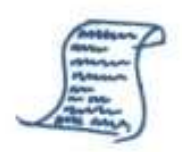

Publicações

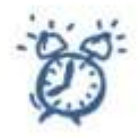

Defesas

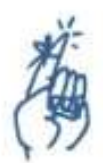

Exposições

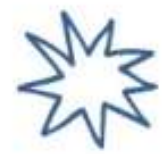

Noticias e eventos

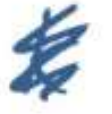

Bastidores

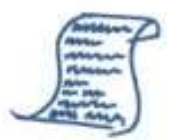

\section{Publicações}

- Lisbon, Henriqueta. Obra completa: Poesia, Poesia traduzida e Prosa. Organização Wander Melo Miranda e Reinaldo Martiniano Marques. São Paulo: Editora Peirópolis, 2020. 3 volumes.

- LISPECTOR, Clarice. Todas as cartas. Prefácio e notas: Teresa Montero; Pesquisa textual e transcrição das cartas: Larissa Vaz. Rio de Janeiro: Rocco, 2020.

- Melo Neto, João Cabral de. Poesia completa. Organização, estabelecimento de texto e notas: Antonio Carlos Secchin, com a colaboração de Edneia R Ribeiro. São Paulo: Companhia das Letras, 2020. (Selo Alfaguara)

- SouZA, Risonete Batista de; BORGES, Rosa; AlmeidA, Isabela Santos de; SouZA, Débora de. (org.). Filologia em diálogo: descentramentos culturais e epistemológicos. Salvador: Memória \& Arte, 2020.

- Willemart, Philippe L. M. G.. Les mécanismes de la création littéraire: lecture, écriture, génétique et psychanalyse. 1. ed. Oxford: Peter Lang, 2020.

\section{Defesas da área de crítica genética}

- Dall Alba, Julia Daroll. A poesia de Ernani Fornari: recuperação e fixação de éditos e inéditos. 2020. Tese (Doutorado em Programa de Pós-Graduação em Letras) - Pontifícia Universidade Católica do Rio Grande do Sul. Orientadora: Maria Eunice Moreira.

- DiAs, Kenia. Obras em processo nas artes cênicas: estudos dos diários de montagem da peça Nós do Grupo Galpão/MG e Prática Aisthesis/DF. 2020. Tese (Doutorado em Comunicação e Semiótica) - Pontifícia Universidade Católica de São Paulo. Orientadora: Cecilia Almeida Salles.

\footnotetext{
${ }^{1}$ Doutor em Estudos Literários pela Fale-UFMG. E-mail: clabrac1980@gmail.com
} 
- Koyano, Amayi Luiza Soares. Michel Butor e a parole em cores: das entrevistas literárias à criação. Início: 2020. Dissertação (Mestrado em Estudos Linguísticos, Literários e Tradutológicos em Francês) Universidade de São Paulo. Orientadora: Claudia Consuelo Amigo Pino.

- SAntos, Libânia da Silva. Provas de "francesia": análise de autoria e edição semidiplomática de documento apreendido no contexto da Conjuração Baiana. Início: 2020. Dissertação (Mestrado em Programa de PósGraduação em Língua e Cultura) - Universidade Federal da Bahia. Orientadora: Alícia Duhá Lose.

\section{Noticias e eventos}

- A Editora Peirópolis, em comemoração aos 120 anos de Henriqueta Lisboa, além de publicar a Obra completa da poeta, em três volumes, criou um site que disponibiliza a versão digital das mais de 2 mil páginas do conjunto. No endereço é possível acessar correspondência, fac-símiles, fortuna crítica e manuscritos. Mais informações: https://www.editorapeiropolis.com.br/henriqueta-lisboa/

- Em homenagem ao centenário de Clarice Lispector o Instituto Moreira Salles, responsável pelo seu acervo desde 2004, lançou um site dedicado à escritora, sob coordenação de Eucanaã Ferraz. O espaço reúne fotos, manuscritos, áudios, vídeos, cartas, aulas e textos críticos. Para saber mais, acesse: https://claricelispector.ims.com.br/

- A revista Criação \& Crítica está com chamada aberta para submissão de artigos até o dia 15 de abril de 2021. Para mais informações acesse: https://www.revistas.usp.br/criacaoecritica/announcement/view/1002 